\title{
Micro, Small, Medium Enterprises Business Empowerment to Creative-Halal Industry: Street Food in Bangkok
}

\author{
Afni Regita Cahyani Muis ${ }^{1}$, Riska Luneto ${ }^{2}$, Dita Nur Safitri ${ }^{3}$ \\ \{afniregita@unida.gontor.ac.id ${ }^{1}$ \} \\ Universitas Darussalam Gontor, Indonesia ${ }^{1,3}$ \\ Universitas Islam Negeri Alauddin Makassar, Indonesia ${ }^{2}$
}

\begin{abstract}
The study was conducted to see the development of new variables in strengthening MSMEs, especially Bangkok Street Food, strengthening an industry in a country driven by existing stakeholders, such as government, society, and business actors. The potential Bangkok Street Food is also supported by a large market that is not only consumed by the local community but also draws attention for foreign tourists. The dynamics of street food creates a competitive business competition so that MSMEs engaged in the culinary field are required to have creativity in managing its business. Creative culinary business must also be supported by the tastes of communities that are oriented to halal food. Creative-Halal industry becomes a collaboration of the creative industry sector with a sharia-based processing which is called halal industry. The study aims at Bangkok Street food that collaborates with the creative-halal industry in empowering a potential business sector in Thailand. The study also provides the halal industry that has a significant effect on strengthening MSMEs. The method used a qualitative method with primary data, as such question and answer session in the International Halal conference which was held in University of Darussalam Gontor. And secondary data, as though literature study, report, and official website. The study is aimed at Bangkok Street Food that can be a recommendation for developing states to improve the business in the culinary industry.
\end{abstract}

Keywords: MSMEs, Creative Industry, Halal Industry, Bangkok Street Food

\section{Introduction}

The development of human resources is significant to the enhancement of economic competitiveness. Nowadays, people are required to have skills in developing business potential. In the digitalization era, Micro, Small-Medium Enterprises (MSMEs) are increasingly opening up business opportunities to the community. The business power of MSMEs is contributing to ongoing economic activity in the country when experiencing an economic deficit.

The Organization for Economic Cooperation and Development (OECD) said that MSMEs have played an important role in the transition and development of a country. In this globalization era, transition and developing countries encourage their businesses to face challenges by increasing human institutional resources capacity. Enhancement of MSMEs in increasing domestic competitiveness towards the global market [1]. 
The dynamics of business growth created by MSMEs can be sustainable by building community creativity. Creative industries that are based on MSMEs will foster creativity skills, innovation, and community by economic value. MSMEs have been proven by highincome countries, such as the United Kingdom, the United States, Europe Union, Japan, South Korea, and China.

Positive business growth by MSMEs is also in line with employment and trade growth. The Gross Domestic Product (GDP) total of high, low, and middle-income countries, each have a percentage of $55 \%, 60 \%, 70 \%$. With each total workforce of $65 \%, 70 \%$, and $95 \%$ [2].

Currently, the opportunities which are developing are culinary. With social media existence, people can easily get culinary advertisements that are scattered in various countries. Each country has its culinary uniqueness that can build the tourism sector. Street food is popular in the culinary industry presently.

Bangkok street food is a great example of the existence of world street food. The collaboration with creative and halal industries for Thai culinary is a great opportunity in increasing the business sector of the local community as well as sparking tourism objects and gastro diplomacy.

The development of the Muslim population has created opportunities for diversification of halal products in the global market which indirectly affects the Muslim community needs for halal products, both domestic or foreign tourists.

\section{Method}

The used methodology was a qualitative method. Specifically, primary and secondary data. Primary data was obtained by discussion, asking question and answer session in the UGO Healthy International Conference "The Role of Health Professional in Halal Industry Solving Contemporary Issues of Covid-19" at the University of Darussalam Gontor. The secondary data was collected by literature studies, such as journals, reports of the government institutions, dissertation research, and official websites of related institutions.

\section{Results and Discussion}

The Thai government has prioritized the creative industry as human creativity that creates useful values. They were creating a creative economy and workforce as important factors of production. The creative industry has a significant impact on the country's economy in various sectors. As one of the Southeast Asian countries, Thailand is known for its cultural diversity, history, and culinary delights that are spread throughout the province. Thai government policy builds creative business potential by promoting "Thai Identity", such as cultural tourism, traditional Thai medication, Thai massage, Thai food, supporting software, film and music industries, and also Thai design (Kyoto Review, 2015). The popular one is culinary.

Table 1. Creative Industry Cluster in Thailand

\begin{tabular}{|c|c|c|c|}
\hline Cultural Heritage & Arts & Media & Functional Creation \\
\hline Thai crafts Eco-tourism & Performing arts & Films and video & Design Fashion \\
\hline Thai food Traditional & Visual arts & Printing & Architecture \\
\hline
\end{tabular}




\begin{tabular}{|c|c|c|c|}
\hline Thai medication & & Broadcasting & Advertisement \\
\hline & & Music & Software \\
\hline
\end{tabular}

MSMEs have large business potential through the creative industry. Thailand's MSME transition was realized to face the ASEAN Economic Community in 2015. In 2012, the "Thailand Competitiveness Report" was developing the creative economy by utilizing geographic location, knowledge-based infrastructure, and upgrading skills of MSMEs to increase the value of goods and services [3]. Thai MSMEs under the Ministry of Industry shows that there are 2.9 million MSMEs with $99 \%$ of the number of entrepreneurs, then they contribute $37.2 \%$ with a total export value of 1.59 trillion baht. The Thai government's policy orientation in developing MSMEs have 4 strategies: 1) creating investment for business operations, 2) increasing competitiveness, 3) creating a balance of business, social and environmental development, 4) increasing the potential of MSMEs in the international economy [4].

The food industry is an important contributor to Thai economy. The Thailand food industry became the 10 largest producers and exporters of processed food products with $28.3 \%$ of total GDP. Thai society also relies on MSMEs for their livelihoods. The community's survival from MSMEs directly affects people's living standards [4].

\subsection{Halal Food Industry in Thailand}

To this case, the concept of halal at obtaining food and drinks that are thayyib (good) as stated in the Qur'an and Hadith. It means that not all halal foods are good. According to AlSaadi on Tayseer Al-Kareem from Al-Baqarah 168 that it calls all human beings, believers and non-believers [5]. Likewise, Halal concept in Islam involves quality product consumed, such as hygiene, cleanliness, management to enhance good food from a good process.

One of the efforts to develop the Thai economy is carried out by highlighting the tourism and culinary industry, Thailand has various types of night markets which are one of the destinations for foreign tourists, which offer a wide variety of goods and culinary delights. Halal labeling, especially in the culinary industry, is a form of government and community cooperation to meet market demand and is also a form of gastro diplomacy for Thailand itself.

As a country dominated by non-Muslims, Thailand have oriented with halal tourism development in line with the massive development of Muslim tourism besides diaspora and a growing Muslim population in Thailand. Although the main objective of tourism authorities is to increase tourist visits, Thai government also pays attention to broader goals, namely to build an inclusive society, prevent religious and ethnic conflicts, and contribute to the third pillar of ASEAN integration, which is socio-culture.

Thailand has developed Halal Food as a new strategy to increase Muslim tourists to visit Thailand. The Thai government hopes that Halal Food can provide and serve tourists with guaranteed safety standards for consumption by the wider community. The development of the halal market has been started for a long time until Thailand was able to enforce halal certification nationally by The Central Islamic Committee of Thailand. This was done to minimize the misuse of halal codes that would confuse Muslim consumers [6]. The potential of halal concept is not only for Muslim tourists but also as food safety management with healthy standards for all mankind.

The halal food industry is one of 11 products that are the government's target and focus in order to be massively promoted. Because halal food is not only intended to "sell food", indeed trying to expand the demand for logistics and other related industries [7]. The main 
actors in the Thai halal food industry are BRF, Nestle, QL Food, Saffron, Street Food, Halal Meat, Friend Food, Cargill, Al-Falah, Prima Agri-Products, Tahira Food, and so on [8].

Thailand has a Muslim population in several regions, such as Pattani, Songkhla, and Yala. They also support the existing culinary diversity. The Thai government through The Board of Investments has made efforts to strengthen the halal food sector with investment to increase the entrepreneur's competitiveness and diversification of local products and $R \& D$. In addition, The Halal Standards Institute is also present as a government effort to support halal products, it is noted that there are 2,555 producers and more than 50,000 products that have received halal certification from this organization [9].

The efforts to develop Thailand's halal industry in the culinary sector also indirectly include to Halal Tourism. Halal food as one of the National Branding in the tourism sector.

\subsection{Creative and Halal Industry in Bangkok Street Food}

Thai government is developing creative industries with a significant role in the tourism sector. This is implemented in MSMEs Designated Areas for Sustainable Tourism Administration (DASTA). This interest empowers local communities and encourages Sustainable Tourism Management which creates Creative Tourism [10].

According to UNWTO (2012), food tourism is the most creative and dynamic segment which is increasing rapidly. Food tourism is also known as cuisine tourism or gastronomic tourism. Food tourism is a motivation for traveling by visiting food producers, food festivals, restaurants, and certain locations as attributes in those areas. It makes a travel experience that one learns, appreciates and consumes local culinary resources. According to Global Food Trends, the term gastronomy is defined as a strategic element to establish a brand image in one destination [10].

In 2015, Bangkok was ranked first as the most popular destination in Asia Pacific by the MasterCard Asia Pacific Destination Index. It became World Best City in 2008, 2010, 2011, and 2012 by Travel \& Leisure Magazine. Thus, it also became one of the World's best gastronomy destination cities in Tasty Street Food [11]. Bangkok Street Food is one of the world-famous culinary markets which is located in the heart of Thailand and the most frequently visited by foreign tourists. The notable places such as Chinatown, Old Town, Sukhumvit, Silom and Sathorn, and Saphan Lueng. Finding halal culinary in Bangkok is in areas close to mosques, such as Ramkhamhaeng, Pratunam, Samat Muslim Food.

The atmosphere of MSMEs street food business is supported by entrepreneurial interest and company capabilities. This is supported by the role of startups that expand the Thai culinary business. The entrepreneurial spirit emerges from individual characteristics in building MSMEs, such as entrepreneurial training, new knowledge, technology, new products, self-confidence, good planning readiness, and innovative solutions. The company's capabilities play an important role in marketing, financial planning, control, and sustainable human resource management. The support of the Thai government to encourage the MSMEs capability is by accelerating new MSMEs for sustainable MSMEs operations, as though holding training programs that involve educational institutions [4]. The capacity building created an effort to encourage competitive advantage, as according to Porter [12], such as directors, aggressive strategies and implementation.

The significance of street food that builds MSMEs in Bangkok can be encouraged by applying the halal concept. The legalization of halal concept is proven by the development of halal certification. In Thailand, there are 4 stages of halal certification development. First, Halal 1.0, which was established before 1949. The halal status of products and services for 
Muslim consumers was assessed only based on the opinion of the ulama without an authentication process and paper certification. Second, Halal 2.0 represents the industrial development effort from 1949 to 1997 when the Shiekul Islam office issued halal certificates in treatment centers for the first time. Meanwhile, Halal 3.0 started from 1997 to 2016 where the Codex-based Halal Standard Institute of Thailand was launched. In 2002, the Thai Islamic Central Committee (CICOT) succeeded in gaining the trust of the Thai government with a strategic approval of the establishment of a halal food center in southern Thailand. This support was continued with the allocation of funds to develop halal-HACCP system in 2003. Fourth, halal 4.0 starting from 2017 until now. The halal logo will be the second brand for halal products, services, certifications to be linked to IoT, cloud, e-commerce, and others [13].

The existence of street food is developed with various types of food festivals such as Chatuchak Night Market which is a festival that known as delicious street food. The existence of Go-Digital, the management of Thai tourism website, specifically made access Thai restaurant locations, both within Thailand and outside Thailand [6].

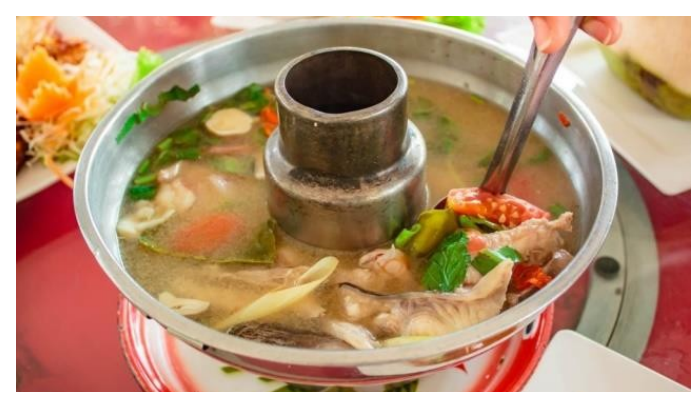

Fig. 1. Tom Yum Goong, Holidayme.

Some of the famous halal foods are also Thai specialties, such as Som Tam (Green Papaya Salad), Tom Yum, Mango Sticky Rice, Thai Sweet Crepe (Khanom Buang), Fried Quail Eggs, Thai- Style Fried Chicken (Gai Tod), Thai Coconut Hot Cakes (Kanom Krok), Red Ruby (Tab Tim Krob), Thai Coconut Ice Cream, Thai Stir-Fried Noodles (Pad Thai), Thai Milk Tea (Cha Yen), Thai Pancake (Rotee), Mataba Bread, Barbecued Meat Skewers [14].

According to Halal Trip, they are halal street food that well-known in Bangkok for Muslim travelers. It can be found in Chinatown, Petchaburi Road Soi 7, Bobae Market, Sukhumvit Soi 3, Ramkhamhaeng Street, Asoke Road, and South Charoen Krung Road.

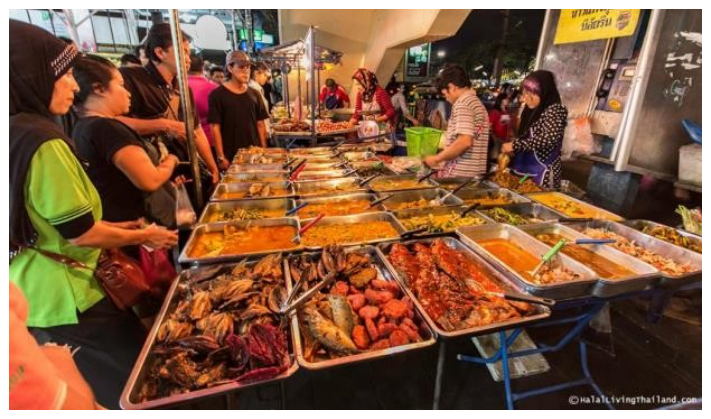

Fig. 2. Ramkhamhaeng Street, Halal living Thailand. 
Labeling the halal logo in a country with a majority of non-Muslim religions is a new habit that is starting to be adopted by several countries, considering that one of the goals of foreign tourists visiting a country is also to enjoy some of its culinary offerings. Thailand, as one of the countries in the Southeast Asia region that has and is quite close to several Muslimmajority countries in the region has also started to follow this, besides that, several regions in Thailand itself also have a few Muslim community.

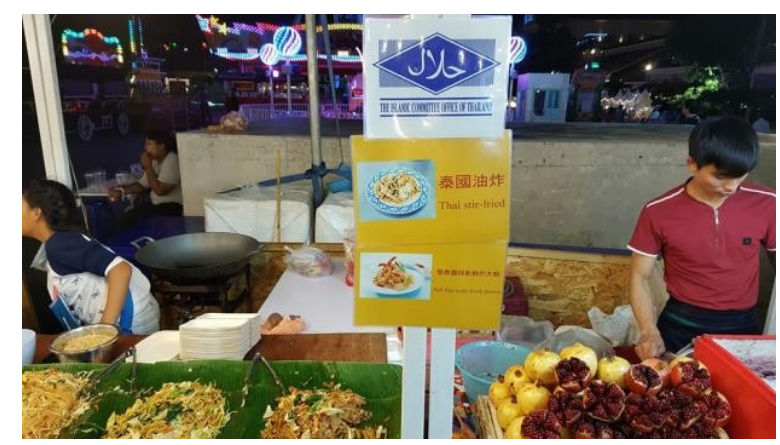

Fig. 3. Food Labelling in Thailand, The Islamic committee office Thailand.

In fact, labelling halal food in Thailand still owned by the restaurant. Meanwhile, halal street food in Bangkok still many that are not certified because food labeling in any type is still in its infancy. Halal food labelling for street food in Bangkok uses conventional logo without being passed by CICOT due to the fee is still fairly expensive and the lack of MSME's knowledge to adding value with halal certificate.

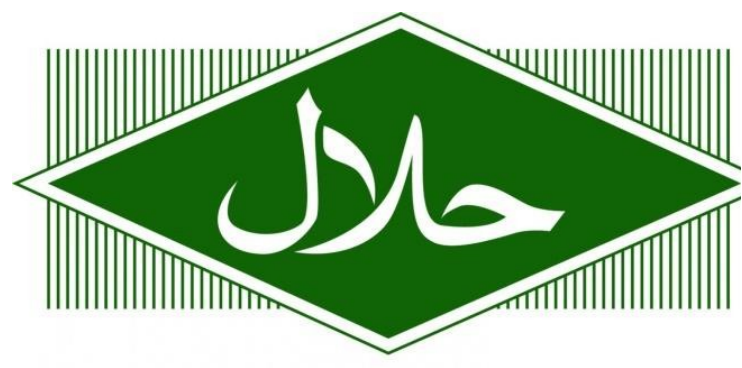

\section{THE ISLAMIC COMMITTEE OFFICE OF THALLAND}

Fig. 4. Halal labeling in Thailand.

Then, the collaboration street food with halal certification has a great potential for Thailand's business development due to the location of street food is usually strategic and the price is relatively affordable. Furthermore, Thailand has a lot of street food leading on social media. So, it can be empowered by the Thai government to provide halal certification for street food visited by many Muslim tourist. 


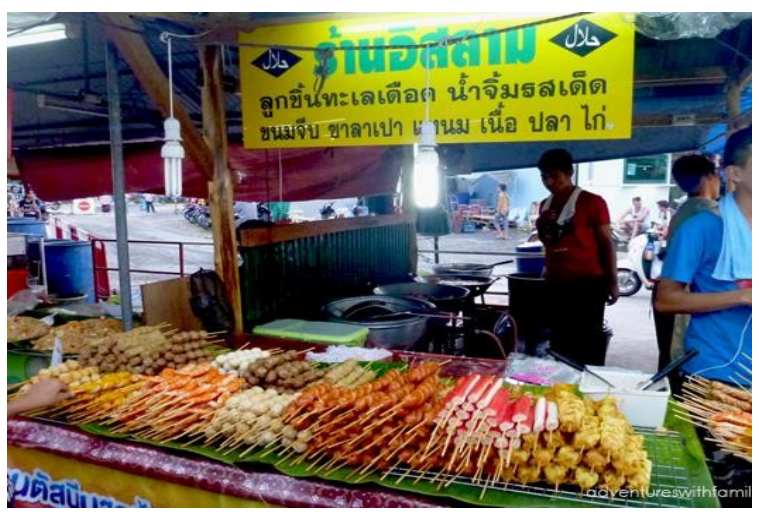

Fig. 5. Halal Thai Street Food.

The potential for developing halal industry through street food is supported by the increasing demand for halal foods. Thailand was the 13th position of halal food producer in the world besides Singapore, Malaysia, Indonesia, Brunei, UAE, Saudi Arabia, and Egypt, with export values by an average growth of $8 \%$ until 2016. Halal certification developed over 68 years has established more than 8,000 factories and more than 150,000 products having halal certification [9]. The ease of access to the street food market is also enhanced by empowering digitalization through an application with a food delivery system.

\section{Conclusion}

Bangkok Street Food is the treasure of the country in developing the culinary industry sector by applying the concept of creative and halal industry. This collaboration is interesting because Thailand as a country is not dominated Muslim communities. The Thai government encourages MSMEs to looking forward creating Muslim-

friendly tourism along with increasing Muslim population. The concept of culinary in creativity is more likely to become a combination of modernized Thai food. The concept of halal is not only aimed at Muslim communities, but also for food safety. Increasing the culinary business through the existence of Bangkok Street Food is a recommendation for developing countries having a special taste in their cultural diversity in order to create competitive advantage with improving human resources. It can lead to competitiveness for a country in the global market.

\section{References}

[1] D. Storey, "Promoting entrepreneurship and innovative SMEs in a global economy: towards a more responsible and inclusive globalisation," in Second OECD Conference of Ministers responsible for Small and Medium-sized Enterprises (SMEs), Istanbul, 2004.

[2] D. Ardjouman, "Factors influencing small and medium enterprises (SMEs) in adoption and use of technology in Cote D'ivoire," Int. J. Bus. Manag., vol. 9, no. 8, p. 179, 2014.

[3] C. Srinuan, "Demand for internet access and use of Small and Medium Enterprises (SMEs) in Thailand," 2014.

[4] S. Yu, "Key Determinants for Thai SME's Success: A Study of Thai Food Enterprises in 
Bangkok Metropolitan District.” Bangkok University, 2016.

[5] M. C. Nafis, "The concept of halal and thayyib and its implementation in Indonesia," J. Halal Prod. Res., vol. 2, no. 1, pp. 1-5, 2019.

[6] Y. Fartiannur, "Kepentingan Thailand dalam melakukan," Socio-humanities A J. Soc. Sci. Humanit., vol. 6, no. 4, pp. 1565-1582, 2018.

[7] M. Safira, "Thailand Ingin Masuk dalam 5 Eksportir Makanan Halal," Detik News, 2015. [Online]. Available: https://food.detik.com/info-halal/d- 2997727/thailand-ingin-masuk-dalam5-eksportir- terbesar-makanan-halal. [Accessed: 22-Aug-2020].

[8] H. Pohan, "Di Balik Sukses Industri Halal Thailand," DailyNews, 2019. [Online]. Available: https://www.dailynewsindonesia.com/kolom/haz- pohan/di-balik-sukses-industri-halal-thailand. [Accessed: 22-Aug-2020].

[9] The Board of Investment, "Medical and Halal Food Products Add to Huge Industry in Thailand," The Board of Investment, 2011. [Online]. Available: https://www.boi.go.th/tir/issue/201103_21_3/42.ht m. [Accessed: 15-Aug-2020].

[10] J. Srihirun and M. Sawant, "Creative Tourism through food activities in Thailand."

[11] G. Shea, "Best 23 Cities for Street Food from Miami to Tokyo," CNN Travel, 2018. [Online]. Available: https://edition.cnn.com/travel/article/best-cities- street-food/index.html. [Accessed: 26-Aug-2020].

[12] M. E. Porter, "Competitive strategy: Techniques for analyzing industries and competitors," Compet. Strateg. New York Free, 1980.

[13] H. S. Jenatabadi and C. W. Jasimah, "Halal Food Industry in Thailand: History, Prospects and Challenges." South Korea: Sejong University, 2017.

[14] Sufinas, "14 Must Try Muslim Friendly Street Food in Bangkok," HHWT, 2016. [Online]. Available: https://www.havehalalwilltravel.com/blog/muslim- friendly-street-food-bangkok. [Accessed: 26-Aug-2020]. 